\title{
Differential thermal analyses of the Pleistocene dolomite in southern Okinawa, the Ryukyu Islands
}

\author{
KiYoshi KANEShima ${ }^{1}$ and TADASHI FuJinUKI ${ }^{2}$ \\ Department of Chemistry, Science and Engineering Division, \\ University of the Ryukyus, Naha ${ }^{1} 903$, and Geochemistry \\ and Technical Service Department, Geological \\ Survey of Japan², Kawasaki 213, Japan
}

(Received July 10, 1972; in revised form April 5, 1973)

\begin{abstract}
Differential thermal analyses were conducted on protodolomite bearing carbonate rocks of the Riukiu limestone in southern Okinawa. The light-colored portion which is composed of protodolomite and calcite shows two endothermic peaks, while the dark-colored portion shows three endothermic peaks at $780 \sim 790^{\circ} \mathrm{C}$ (medium), $800 \sim 810^{\circ} \mathrm{C}$ (weak), and $925 \sim 935^{\circ} \mathrm{C}$ (strong), respectively. These three endothermic peaks indicate the occurrence of ferroan-dolomite, protodolomite and calcite.

The occurrence of pyrite was also confirmed by DTA, X-ray and chemical analyses of residues of the dark-colored samples insoluble in dilute hydrochloric acid.

It is concluded that the dark-colored portion is composed of calcite, protodolomite, magnesian-calcite, ferroan-dolomite, aragonite and pyrite. The dark color and the amount of $\mathrm{K}_{2} \mathrm{Cr}_{2} \mathrm{O}_{7}$-consumption of the carbonate rocks are dependent chiefly on the associated pyrite.
\end{abstract}

\section{INTRODUCTION}

It was reported that dolomite is widely distributed in the dark-gray portions of the Riukiu limestone containing many bivalve and snail fossils in the Koza area of southern Okinawa (KANESHIMA, 1965).

KonisHi et al. (1972) reported a difference in chemical and mineralogical compositions between dark- and light-colored portions of the Pleistocene dolostone from southern Okinawa. The conspicuous depletion of ${ }^{13} \mathrm{C}$, accompanied by enrichment of ${ }^{18} \mathrm{O}$ in the calciferous protodolomites, was ascribed to dolomite formation resulted from alteration of aragonite and magnesian calcite in contact with hypersaline brine in a subtropical shallow subsurface environment.

A thermal study was carried out by the present authors to clarify further difference in mineralogical composition between dark- and light-colored portions of the Pleistocene dolomite described by KONISH et al. (1972). It was clearly observed that a differential thermalgram of the dark-colored portion shows three endothermic peaks at $780 \sim 790^{\circ} \mathrm{C}$ (medium), $800 \sim 810^{\circ} \mathrm{C}$ (weak) and $925 \sim 935^{\circ} \mathrm{C}$ (strong).

Kulp et al. (1951) and WEBB and HEYSTEK (1957) conducted differential thermal 
analyses of Ca-Mg-Fe carbonate minerals, but they did not mention the characteristic endothermic peak with two steps which appear at 780 and $810^{\circ} \mathrm{C}$. FuJinuki (1970) conducted DTA of the Riukiu limestone from Kikai-jima, and reported endothermic peak with two steps at 730 and $810^{\circ} \mathrm{C}$ but did not discuss the reason why the peak shows two steps.

The present paper reports the result of the thermal and chemical studies on the dark-colored carbonates from southern Okinawa with the intention of elucidating the nature of the protodolomite in the Riukiu limestone and the possible mechanism of the dolomite formation.

\section{EXPERIMENTAL}

Powdered samples $(0.28 \sim 0.34 \mathrm{~g})$ were used for DTA analyses with a Rigaku Denki differential thermal analyzer. The sensitivity of DTA was $100 \mu \mathrm{V}$ and the rate of heating was $10^{\circ} \mathrm{C} / \mathrm{min}$. A dissolution experiment was performed with the following two procedures: (a) Ten grams of the powdered sample of the dark-colored portion was mixed with $5 \mathrm{ml}$ of water and ground for $30 \mathrm{~min}$ in an agate mortar; the residues were filtered off and washed with water. (b) Ten grams of the powdered dark-colored portion of carbonate was dissolved in $100 \mathrm{ml}$ of $0.5 \mathrm{~N}$ and/or $2 \mathrm{~N}$ hydrochloric acid and the solution was filtered.

The mineralogy of the residual matters was identified by DTA and X-ray diffraction method. The carbonate samples and insoluble residues were analyzed as follows: $\mathrm{CaO}, \mathrm{MgO}, \mathrm{Al}_{2} \mathrm{O}_{3}$ and $\mathrm{Fe}_{2} \mathrm{O}_{3}$ by chelatemetry; $\mathrm{SiO}_{2}$ and $\mathrm{SO}_{4}$ by gravimetry; and $\mathrm{Fe}(\mathrm{II})$ by $\mathrm{KMnO}_{4}$ volumetry.

\section{RESUlts AND Discussions \\ DTA of magnesian calcite : DTA curves of two representative protodolomite} samples from southern Okinawa are shown in Fig.1. As seen from Fig.1, the lightcolored sample 39-2 which is composed of calcite and protodolomite shows two endothermic peaks; the low temperature peak at about $790^{\circ} \mathrm{C}$ is about one-third of the amplitude of the high temperature peak at about $937^{\circ} \mathrm{C}$. The dark-colored sample 37-14 which is composed of calcite, protodolomite, magnesian-calcite and aragonite shows three endothermic peaks at about $780^{\circ} \mathrm{C}$ (medium), $805^{\circ} \mathrm{C}$ (weak), and $925^{\circ} \mathrm{C}$ (strong).

The DTA curve of several dark-colored protodolomite samples from southern Okinawa are shown in Fig.2. All dark-colored portions show three endothermic peaks; the first endothermic peak at $780 \sim 810^{\circ} \mathrm{C}$, immediately followed by a short endothermic peak at $800 \sim 810^{\circ} \mathrm{C}$ and succeeded in turn by a strong endothermic peak at $925 \sim 935^{\circ} \mathrm{C}$. These characteristic endothermic peaks with two steps at about $800^{\circ} \mathrm{C}$ were also observed by FujInUKI (1970) in the Pleistocene Riukiu limestone from Kikai-jima Island. 
The experiments described below were initiated in order to see the reasons why the dark-colored samples show three characteristic endothermic peaks as seen in Fig. 2. As the dark-colored portions contain magnesian calcite, the DTA curves of the presentday marine carbonate sediments containing 4.05 to $5.14 \%$ of $\mathrm{MgO}$ in magnesian calcite were examined for comparison, as given in Fig.3.

The marine carbonate sediments are composed of Mg-rich calcite (magnesian calcite), Mg-poor calcite and aragonite. The endothermic peak at $740 \sim 785^{\circ} \mathrm{C}$ might appear by decomposition of $\mathrm{MgCO}_{3}$ in magnesian calcite. The characteristic peak with two steps as shown in Fig.2, however, is not found in Fig.3. These facts suggest that the endothermic peak at $800 \sim 810^{\circ} \mathrm{C}$ does not appear by decomposition of $\mathrm{MgCO}_{3}$ in magnesian calcite.

Occurrence of ferroan dolomite Since three endothermic peaks are considered to be due to the decomposition of ferroan-dolomite (SIEver and GLASS, 1957), the DTA curve of the mixture of dolomite and ankerite was examined to confirm the existence of ferroan-dolomite. Ninety five, 90 and 82 portions of the light-colored protodolostone (39-8A) were mixed with 5,10 and 18 portions of ankerite (Chollapuk Do, Korea $\mathrm{Fe}(\mathrm{II}): 3.56 \%$ ), respectively. DTA curves of the mixed samples are shown in Fig.4. It is seen that the sample 39-8-A-5\%Ank and containing 5\% of

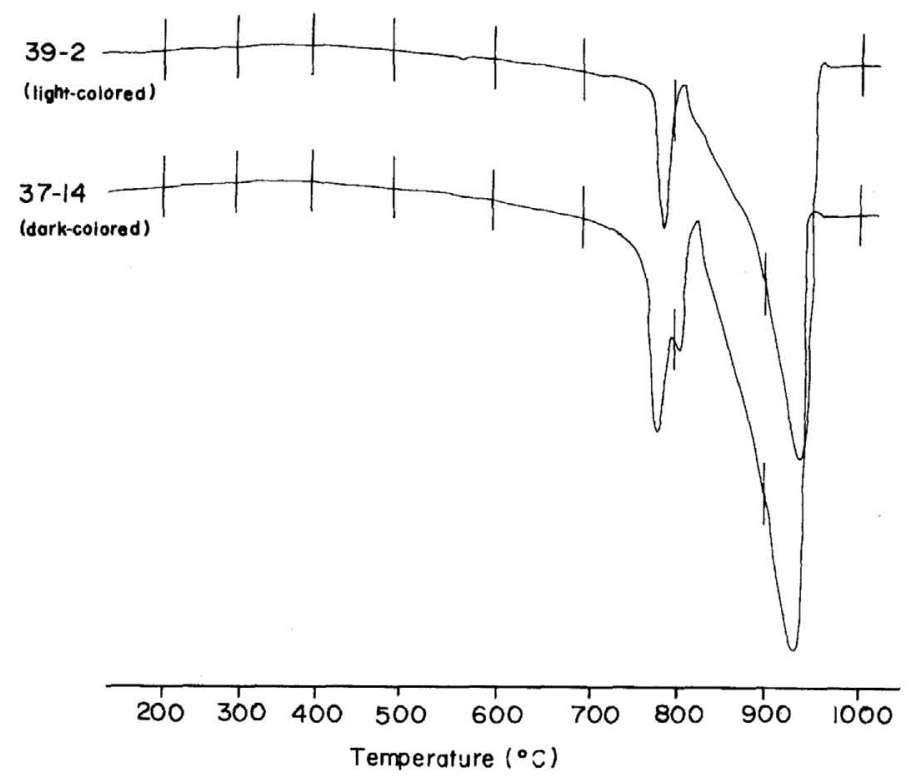

Fig.1. DTA curves of two representative dolostone samples from southern Okinawa, the Ryukyu Islands; 39-2 light-colored portion, 37-14 darkcolored portion: 
ankerite shows the three endothermic peaks at about $790^{\circ} \mathrm{C}, 805^{\circ} \mathrm{C}$ and $925^{\circ} \mathrm{C}$. The temperatures for the three endothermic peaks are identical with those for the three peaks which appear in the dark-colored samples.

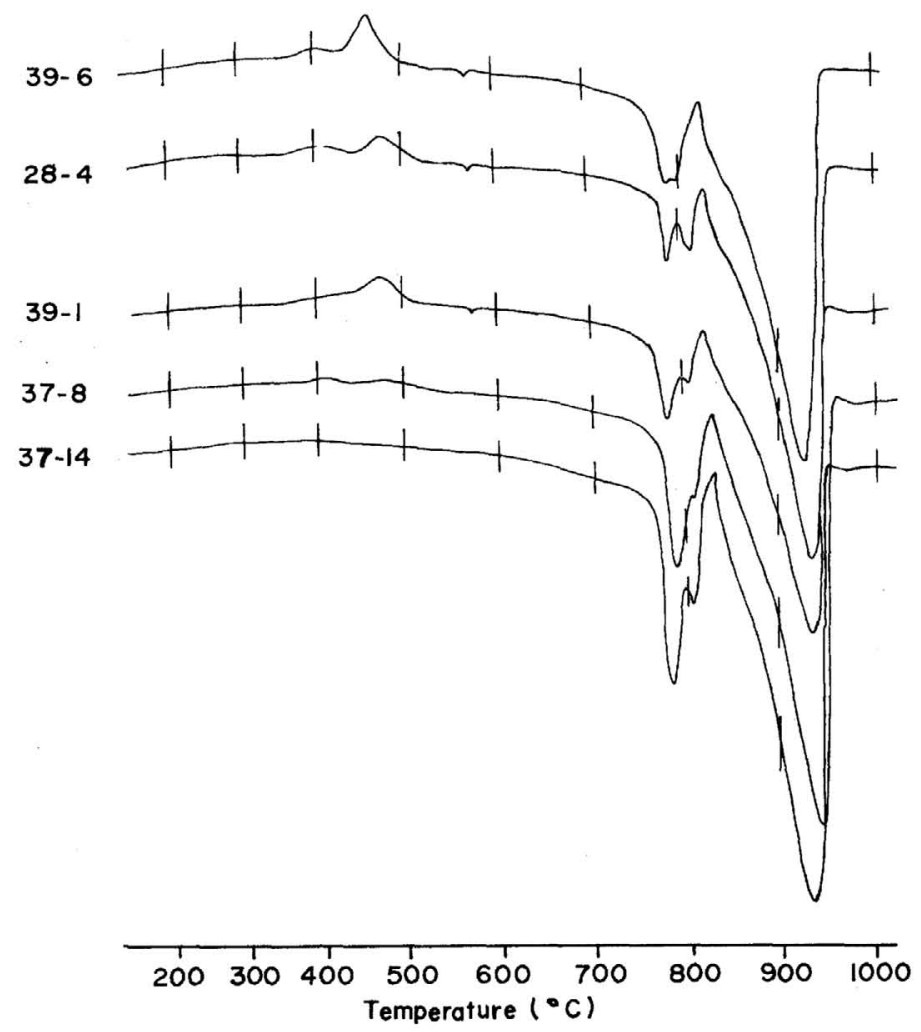

Fig.2. DTA curves of the dark-colored protodolomite-bearing samples from southern Okinawa, the Ryukyu Islands.

Localities; 39-6, 39-1: Koza Saiseki, Gushikawa-shi. 37-8, 37-14: Akamichi, Misato-son. 28-4: Maibara, Gushikawa-shi.

The DTA curves of the mixtures of calcite and ferroan-dolomite were published by SiEver and Glass (1957). They reported that when the endothermic peaks at about 790 and $810^{\circ} \mathrm{C}$ have low amplitudes the carbonate sample contains only a small amount of ferroan-dolomite. The DTA curves of the dark-colored carbonate samples investigated by the present authors are similar to those described by SIEvER and Glass (1957). These facts make it possible to conclude that the dark-colored carbonate samples are composed of calcite, protodolomite and ferroan-dolomite. 


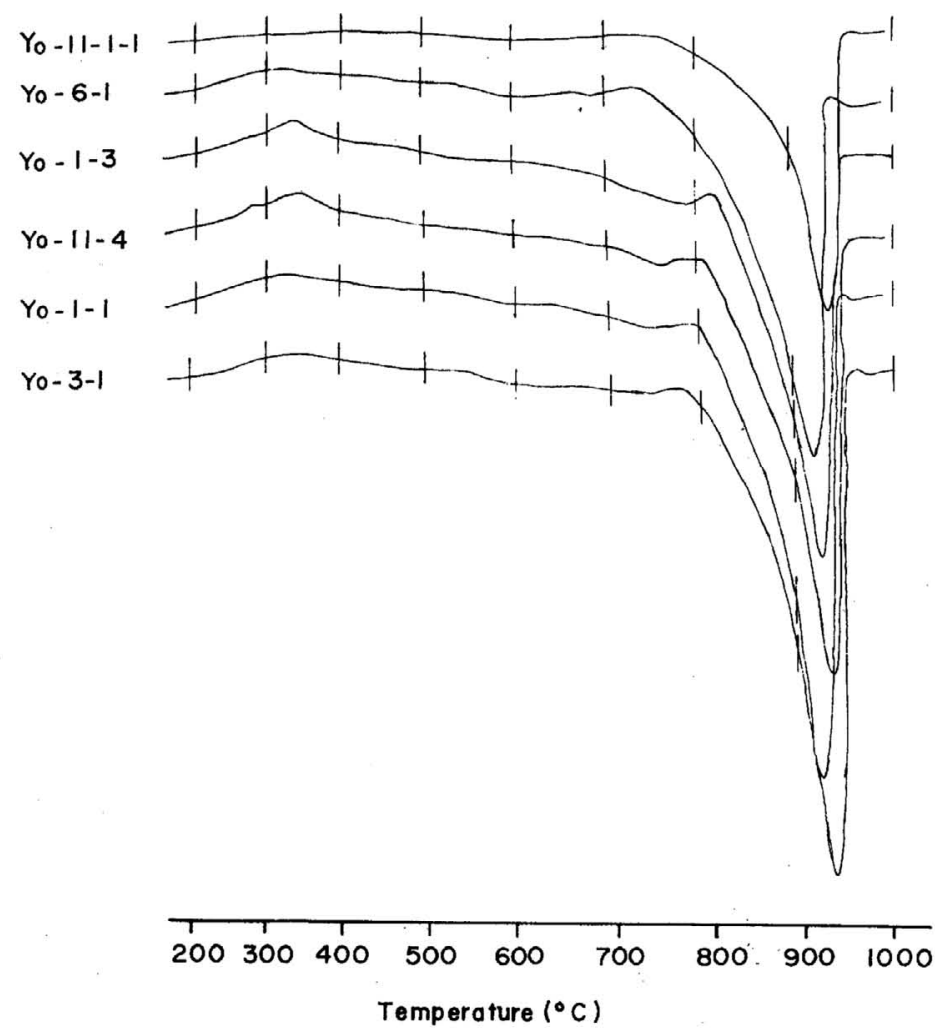

Fig.3. DTA curves of present-day marine carbonate sediments from the Ryukyu Islands. Localities; Yo1-1, Yo1-3: $26^{\circ} 03.2^{\prime} \mathrm{N}, 127^{\circ}$ $44.7^{\prime} \mathrm{E}$. Yo3-1: $26^{\circ} 02.7^{\prime} \mathrm{N}, 127^{\circ} 38.7^{\prime} \mathrm{E}$. Yo6-1: $24^{\circ} 41.5^{\prime} \mathrm{N}, 125^{\circ}$ 01.0 E. Yol1-1-1: $24^{\circ} 23.5^{\prime} \mathrm{N}, 124^{\circ} 04.5^{\prime} \mathrm{E}$. Yo1 1-4: $24^{\circ} 23.5^{\circ} \mathrm{N}$ $124^{\circ} 04.5^{\prime} \mathrm{E}$. $\mathrm{MgO}$ content: Yo11-1-1 5.03\%, Yo6-1 5.14\%, Yo1-3 $4.18 \%$, Yo11-4 4.52\%, Yo1-1 4.11\%, Yo3-1 4.03\%.

To make it sure further, the ferrous iron $[\mathrm{Fe}(\mathrm{II})]$ in the samples was determined by $\mathrm{KMnO}_{4}$-titration. The results of the analysis as shown in Table 1 indicate that the ferrous iron contents of 11 dark-colored portions range from 0.14 to $0.39 \%$ with an average value of $0.28 \%$, whereas those of the light-colored portions range from 0.10 to $0.17 \%$ with an average value of $0.12 \%$. It is obvious that the dark-colored samples contain much larger quantity of ferrous iron than that in the light-colored samples. The fact might support that the dark-colored portions contain ferroan-dolomite.

Dissolution experiments Dissolution experiments were carried out to see the difference in a property between the dark- and light-colored portions of the carbonate samples and to identify the materials showing the endothermic peaks. The DTA 


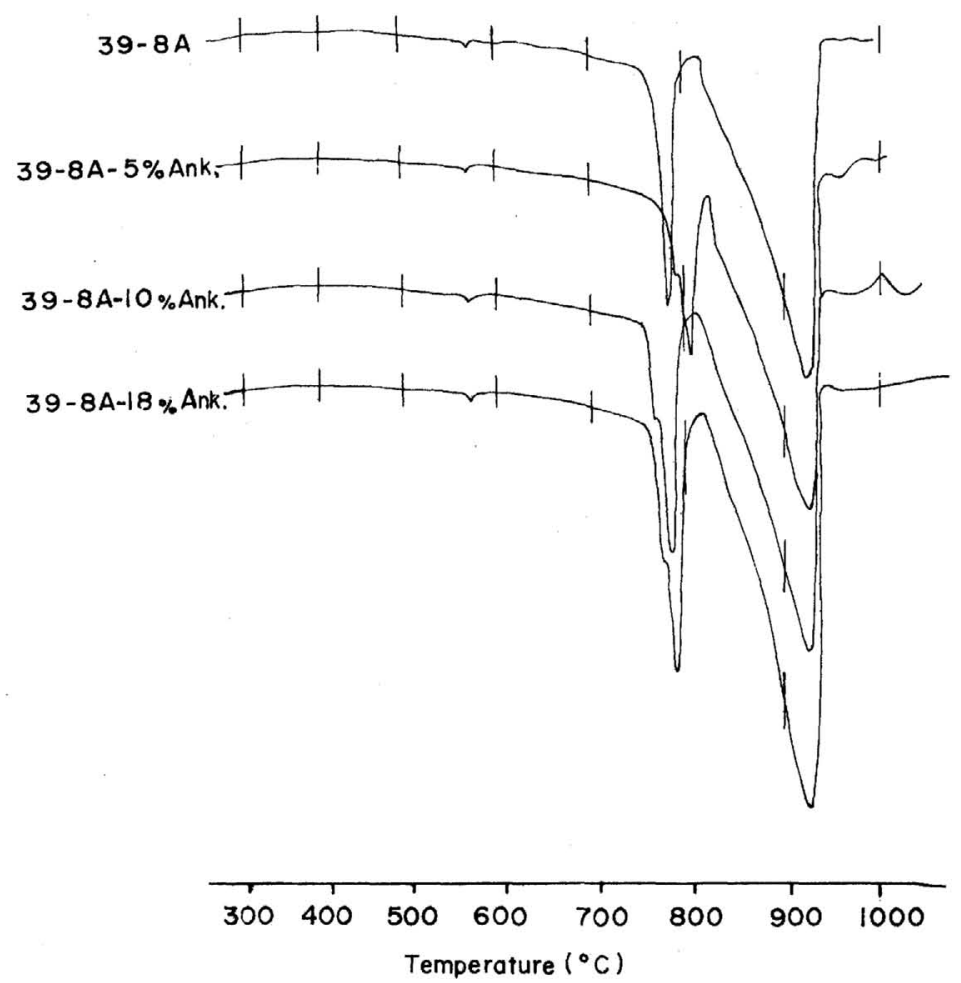

Fig.4. DTA curves of the mixtures of dolostone and ankerite (locality: Chollapuk Do, Korea). 39-8-A: protodolomite-bearing light-colored sample, $39-8-\mathrm{A}-5 \%$ Ank: $5 \%$ ankerite mixture, $39-8-\mathrm{A}-10 \%$ Ank: $10 \%$ ankerite mixture, $39-8-\mathrm{A}-18 \%$ Ank: $18 \%$ ankerite mixture.

Table 1. Chemical composition of the dark- and lightcolored carbonate rocks

\begin{tabular}{lcccccccccccc}
\hline \hline & \multicolumn{1}{c}{ Dark colored sample } & \multicolumn{5}{c}{ Light colored sample } \\
\hline $\begin{array}{l}\text { Sample } \\
\quad \mathrm{No} .\end{array}$ & $\mathrm{Fe}(\mathrm{II})$ & $\mathrm{Fe}_{2} \mathrm{O}_{3}$ & $\mathrm{CaO}$ & $\mathrm{MgO}$ & $\mathrm{SO}_{4}$ & $\mathrm{Sample}$ & $\mathrm{Fe}(\mathrm{II})$ & $\mathrm{Fe}_{2} \mathrm{O}_{3}$ & $\mathrm{CaO}$ & $\mathrm{MgO}$ & $\mathrm{SO}_{4}$ \\
$39-8-\mathrm{B}$ & 0.32 & 0.92 & 34.13 & 9.05 & 0.78 & $39-8-\mathrm{A}$ & 0.17 & 1.34 & 31.67 & 9.95 & 0.04 \\
$37-9$ & 0.26 & 0.45 & 39.01 & 9.68 & 0.39 & $39-2$ & 0.14 & 1.10 & 37.34 & 6.80 & 0.05 \\
$39-1$ & 0.34 & 1.06 & 32.74 & 8.95 & 0.73 & $37-10$ & 0.11 & 0.47 & 41.40 & 7.65 & 0.11 \\
$28-4$ & 0.31 & 0.59 & 36.59 & 8.08 & 0.51 & $28-3$ & 0.12 & 0.86 & 38.92 & 4.74 & 0.01 \\
$39-6$ & 0.25 & 1.19 & 34.83 & 12.25 & 0.81 & $39-16$ & 0.10 & 0.67 & 39.62 & 7.25 & 0.09 \\
$37-14$ & 0.14 & 0.34 & 35.48 & 15.49 & 0.21 & $37-13$ & 0.11 & 0.33 & 46.67 & 5.34 & 0.22 \\
$39-4-\mathrm{B}$ & 0.35 & 0.94 & 35.90 & 8.58 & 0.52 & $39-4-\mathrm{A}$ & 0.16 & 0.87 & 38.64 & 6.21 & 0.11 \\
$37-8$ & 0.17 & 0.49 & 36.69 & 11.82 & 0.28 & $1-3$ & 0.11 & 2.38 & 42.51 & 4.81 & - \\
$39-24$ & 0.39 & 1.31 & 32.69 & 9.32 & 0.90 & & & & & & & \\
$28-1$ & 0.26 & 0.78 & 32.79 & 9.15 & 0.38 & & & & & & \\
$29-2$ & 0.31 & 1.01 & 47.88 & 1.80 & 1.05 & & & & & & \\
\multicolumn{1}{c}{ av. } & 0.28 & 0.82 & 36.25 & 9.46 & 0.59 & av. & 0.12 & 1.00 & 39.59 & 6.59 & 0.09 \\
\hline
\end{tabular}

* Sample number is the same as in KONISHI et al. (1972) 
curves of the residual matters in the dissolution experiment are shown in Fig.5, and the results of chemical analyses are presented in Table 2 . The salient results are as follows: The endothermic peak at about $780^{\circ} \mathrm{C}$ for the sample $37-15-\mathrm{W}$, which is the residual matter in water dissolution, is lower in amplitude than that for the untreated sample $37-15-\mathrm{A}$, whereas the peaks at $805^{\circ} \mathrm{C}$ for the former sample is greater in amplitude than that for the latter sample. The results in Table 2 seem to indicate a difference in $\mathrm{MgO}$ content and $\mathrm{MgO} / \mathrm{SiO}_{2}$ ratio but no difference in ferrous iron content and $\mathrm{Fe}(\mathrm{II}) / \mathrm{SiO}_{2}$ ratio between $37-15-\mathrm{A}$ and $37-15-\mathrm{W}$. These results may indicate that magnesian calcite is more soluble and unstable than the other carbonates such as ferroan-dolomite, protodolomite and $\mathrm{Mg}$-poor calcite.

The sample $37-15-0.5 \mathrm{~N}$, which is the residual matter in $0.5 \mathrm{~N}$ hydrochloric acid, does not give the second short endothermic peak at about $805^{\circ} \mathrm{C}$. It is noted that the light-colored carbonate sample does not give the peak around this tempera-

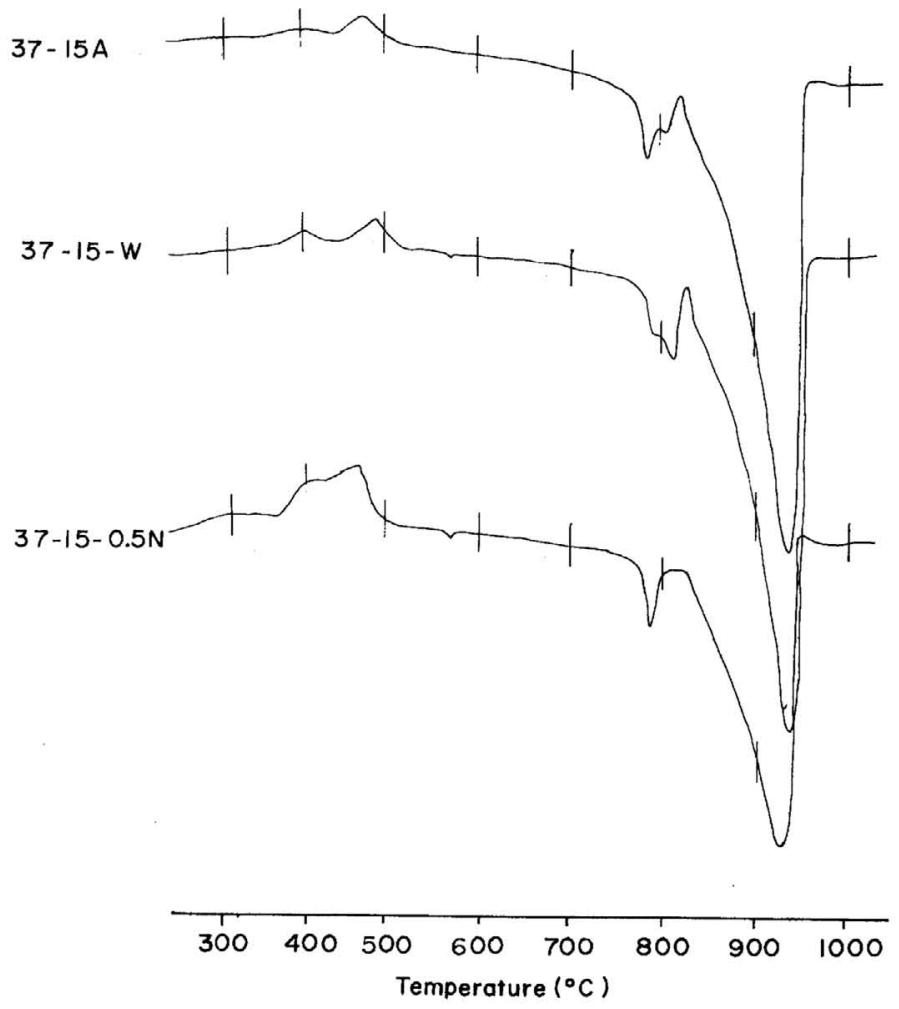

Fig.5. DTA curves of residual matters in dissolution experiment. 37-15-A: dark-colored protodolomite-bearing sample, 37-15-W: treated with water, $37-15-0.5 \mathrm{~N}$ : treated with $0.5 \mathrm{~N}$ hydrochloric acid. 
ture. This fact may support that the ferroan-dolomite is more soluble and unstable in $0.5 \mathrm{~N}$ hydrochloric acid than the protodolomite.

Table 2. Analytical data of carbonate samples and residual matters in dissolution experiment

\begin{tabular}{lccc}
\hline \hline & $\begin{array}{c}\text { Dark colored dolomite } \\
\text { sample No.37-15-A }\end{array}$ & $\begin{array}{c}\text { Treated with water } \\
\text { No.37-15-W }\end{array}$ & $\begin{array}{c}\text { Treated with } 0.5 \mathrm{~N} \mathrm{HCl} \\
\text { solution No.37-15-0.5 N }\end{array}$ \\
\hline $\mathrm{SiO}_{2}$ & $11.19(\%)$ & $11.87(\%)$ & $25.41(\%)$ \\
$\mathrm{Fe}_{2} \mathrm{O}_{3}$ & 0.74 & 0.74 & 1.61 \\
$\mathrm{Al}_{2} \mathrm{O}_{3}$ & 0.36 & 0.34 & 0.68 \\
$\mathrm{CaO}$ & 38.86 & 39.39 & 28.78 \\
$\mathrm{MgO}$ & 6.92 & 6.42 & 6.80 \\
$\mathrm{Fe}(\mathrm{II})$ & 0.30 & 0.31 & - \\
$\mathrm{MgO} / \mathrm{SiO}_{2}$ & 0.61 & 0.54 & 0.26 \\
$\mathrm{Fe} \mathrm{O}_{3} / \mathrm{SiO}_{2}$ & 0.066 & 0.062 & 0.063 \\
$\mathrm{Fe}(\mathrm{II}) / \mathrm{SiO}_{2}$ & 0.026 & 0.026 & - \\
\hline
\end{tabular}

Magnesian calcite and ferroan-dolomite have not yet been found in the lightcolored portions. From these facts, it may be considered that the original state of the carbonates has been preserved in their dark-colored portions, and that the darkcolored portions have changed to the light-colored portions through the processes of diagenesis including weathering, as emphasized by KoNISHI et al. (1972).

Occurrence of pyrite

The appearance of the exothermic peak at about $470^{\circ} \mathrm{C}$ is also characteristic for the dark-colored portions. The DTA curves of seven darkcolored samples are shown in Fig.6, which indicates that all the dark-colored samples give the exothermic peak in the temperature range from 465 to $485^{\circ} \mathrm{C}$.

In order to know the material giving the exothermic peak, the dissolution experiment was carried out. The DTA curves of the residual matters in $0.5 \mathrm{~N}$ hydrochloric acid are given in Fig.5, and the X-ray diffraction data are shown in Table 3. Analytical data for the residual materials treated with dilute hydrochloric acid are presented in Table 4.

Table 4 indicates that the sulfate, iron, aluminum and silica contents of the residual matters increase with increasing concentration of hydrochloric acid. The $\mathrm{X}$-ray diffraction data in Table 3 indicate that the residual matters are composed of quartz, dolomite and a small amount of pyrite.

The occurrence of pyrite was already confirmed by thin section studies and X-ray analysis of dark-colored samples (KonisHi et al., 1972), and was also observed in the Riukiu limestone from Kikai-jima by FuJINUKI (1970). From the DTA curve of $37-15-0.5 \mathrm{~N}$ in Fig.5, thus, it is interpreted that the exothermic peak at about $470^{\circ} \mathrm{C}$ is given by the oxidation of pyrite.

These facts indicate that acid insoluble iron-bearing materials containing sulfate or sulfide are present in the dark-colored portions. 
The fact that a positive correlation apparently exists between sulfate content and $\mathrm{K}_{2} \mathrm{Cr}_{2} \mathrm{O}_{7}$ consumption value (KoNISHI et al., 1972) is considered to be attributed

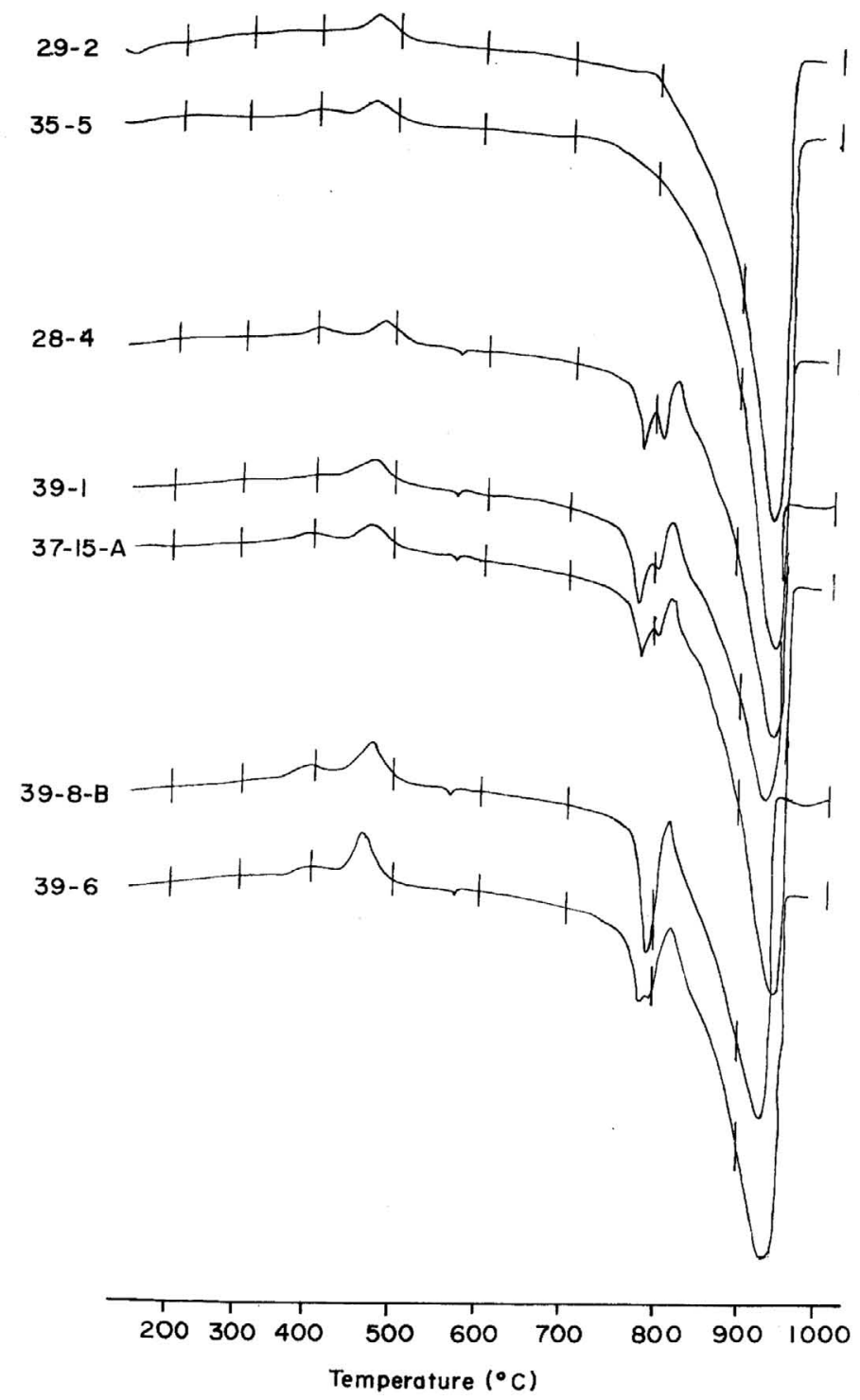

Fig.6. DTA curves of the dark-colored protodolomite-bearing samples from southern Okinawa, the Ryukyu Islands. Localities; 29-2: Kozashi. 35-5: OM Saiseki, Misato-son. 28-4: Maibara, Gushikawa-shi. 37-15-A: Akamichi, Misato-son. 39-1, 39-8-B, 39-6: Koza Saiseki, Gushikawa-shi. $\mathrm{SO}_{4}$ content: $29-2 \quad 1.05 \%, 35-5 \quad 0.19 \%, 28-4 \quad 0.30 \%$, 39-1 $0.39 \%, 37-15-\mathrm{A} \quad 1.26 \%, 39-8-\mathrm{B} \quad 0.27 \%, 39-60.48 \%$. 
Table 3. X-ray diffraction data of residual matters in $2 \mathrm{~N}$ hydrochloric acid

\begin{tabular}{ccrrrrrrr}
\hline Minerals & \multicolumn{2}{c}{$37-15-2 \mathrm{~N}$} & \multicolumn{2}{c}{$39-25-2 \mathrm{~N}$} & \multicolumn{2}{c}{ Pyrite } & \multicolumn{2}{c}{ Quartz } \\
& $\mathrm{d}$ & \multicolumn{1}{c}{$\mathrm{I}$} & $\mathrm{d}$ & $\mathrm{I}$ & $\mathrm{d}$ & $\mathrm{I} / \mathrm{I}_{0}$ & $\mathrm{~d}$ & $\mathrm{I} / \mathrm{I}_{\mathbf{0}}$ \\
\hline $\mathrm{Q}$ & 3.33 & $\mathrm{~V} . \mathrm{S}$ & 3.33 & 84 & & & 3.35 & 1.0 \\
Py & 3.186 & 10 & 3.186 & 7 & 3.10 & 0.5 & & \\
D & 2.967 & 4 & 2.909 & 19 & & & & \\
Py & 2.709 & 5 & 2.709 & 6 & 2.76 & 3.0 & & \\
Q, Py & 2.453 & 13 & 2.453 & 8 & 2.46 & 3.0 & 2.45 & 0.3 \\
D & 2.419 & 3 & 2.419 & 4 & & & & \\
Q & 2.279 & 12 & 2.279 & 5 & & & 2.285 & 0.3 \\
Q, Py & 2.233 & 6 & 2.233 & 4 & 2.24 & 1.0 & 2.235 & 0.1 \\
D & 2.209 & 4 & 2.205 & 6 & & & & \\
Q & 2.126 & 10 & 2.126 & 4 & & & 2.129 & 0.3 \\
Q & 1.979 & 7 & 1.976 & 3 & & & 1.981 & 0.2 \\
Py & 1.914 & 4 & 1.911 & 3 & 1.93 & 2.0 & & \\
Q, Py & 1.817 & 15 & 1.817 & 12 & 1.82 & 0.5 & 1.814 & 0.8 \\
Py & 1.634 & 4 & 1.632 & 4 & 1.645 & 4.0 & & \\
\hline
\end{tabular}

Q: quartz, Py: pyrite, D: dolomite.

Table 4. Analytical data of residual matters in dilute hydrochloric acid

\begin{tabular}{lcccl}
\hline \hline Sample No. & $\mathrm{SO}_{4}(\%)$ & $\mathrm{Fe}_{2} \mathrm{O}_{3}+\mathrm{Al}_{2} \mathrm{O}_{3}(\%)$ & & \multicolumn{1}{c}{ Remarks } \\
\hline $37-15-\mathrm{A}$ & 1.26 & 1.10 & 11.19 & Sample \\
$37-15-0.5 \mathrm{~N}$ & 2.13 & 2.29 & 25.41 & Treated with $0.5 \mathrm{~N} \mathrm{HCl}$ \\
$37-15-2 \mathrm{~N}$ & 6.34 & 6.69 & 84.65 & Treated with 2 N HCl \\
$39-25-\mathrm{A}$ & 0.78 & 2.23 & 19.49 & Sample \\
$39-25-2 \mathrm{~N}$ & 7.97 & 7.92 & 56.20 & Treated with 2 N HCl \\
\hline
\end{tabular}

to the existence of pyrite, because the pyrite content increases with increasing content of sulfate. Sulfate is considered to be the oxidized product of pyrite and a part of the $\mathrm{K}_{2} \mathrm{Cr}_{2} \mathrm{O}_{7}$ consumption value is dependent on the pyrite content.

The dark color may be due to the presence of pyrite and carbon derived from organic matters. The occurrence of pyrite in the dark-colored portions may indicate that the protodolomite was formed in a reductive environment, as stated by KoNISHI (1970), because pyrite is considered to be formed by the reduction of sulfate.

\section{ACKNOWLEDGMENTS}

The authors wish to thank Prof. KENJI KONISHI of Kanazawa University for his valuable advice, and also Prof. TAKeo Watanabe of Akita University for his kind suggestions to this work. We are also greatly indebted to Prof. YASUSH KITANO of Nagoya University for his invaluable advices and critical reading of the manuscript. 


\section{REFERENCES}

FUנINUKI, T. (1970) On the minor elements in Ryukyu limestone from Kikai-jima Island, Kagoshima Pref., Japan. Bull. Geol. Surv. Japan 21, No.5 27-40.

KANESHIMA, K. (1965) Studies on the various kinds of the limestones in the Ryukyu Islands. Bull. Arts and Sci. Div., Ryukyu Univ., No.8 23-54 (in Japanese with English abstract).

Konishi, K., KANeshima, K., NAKAGaWA, K. and SAKaI, H. (1972) Pleistocene dolomite and associated carbonates in south Okinawa, the Ryukyu Islands. Geochem. J. 6, 17-36.

KonISHI, K. (1970) Some topics in carbonate sediments. Chikyukagaku (Geochemistry) 4, 24 35 (in Japanese).

KULP, J. L., KENT, P. and KeRR, P. F. (1951) Thermal study of the Ca-Mg-Fe carbonate minerals. Am. Mineralogist 36, 643-670.

SiEVER, R. and GLASS, H. D. (1957) Mineralogy of some Pennsylvanian carbonate rocks of Illinois. J. Sed. Pet. 27, 56-63.

WEBB, T. L. and HEYSTEK, H. (1957) The carbonate minerals (with some notes on calcium and magnesium hydroxides) R.C. Mackenzie ed., The differential thermal investigation of clay, Chapter XIII, Mineralogical Society (clay mineral group), London. 329-355. 